\section{Breastfeeding up to two years of age or beyond and its influence on child growth and development: a systematic review}

\author{
Lactancia materna por dos o más años y su \\ influencia en el crecimiento y desarrollo infantil: \\ una revisión sistemática
}

\author{
Aleitamento materno por dois anos ou mais e \\ sua influência no crescimento e desenvolvimento \\ infantil: uma revisão sistemática
}

Carlos Delgado 1,2

Alicia Matijasevich 1

\author{
1 Programa de Pós-graduação \\ em Epidemiologia, \\ Universidade Federal de \\ Pelotas, Pelotas, Brasil. \\ 2 Instituto Nacional de Salud \\ del Niño, Lima, Perú. \\ Correspondence \\ C. Delgado \\ Programa de Pós-graduação \\ em Epidemiologia, \\ Universidade Federal de \\ Pelotas. \\ Rua Marechal Deodoro 1160 , \\ 3 o andar, Pelotas, $R S$ \\ 96020-220, Brasil. \\ cdelgado.isn@gmail.com
}

\begin{abstract}
A systematic review was undertaken to identify studies describing the global prevalence of breastfeeding up to two years of age or beyond and its effects on child growth and development. The MEDLINE and LILACS databases were searched without any language or date restrictions, retrieving 3,561 titles. All retrieved titles, $453 \mathrm{ab}$ stracts and 49 full-text articles were read. Articles with maximum breastfeeding duration of over two years were included. An analysis was carried out of 19 articles that met the inclusion criteria resulting in a combined prevalence of breastfeeding at two years of age of $33 \%$ (95\%CI: 0.23; 0.42). Increasing trends towards breastfeeding up to two years of age or beyond were observed in the past decades in South Asia. The six studies analyzing the effects of breastfeeding up to two years of age or beyond on child growth showed contradictory results. No association was found with child development. It is concluded that evidence on the medium-term effects of breastfeeding up to two years of age or beyond is scarce and contradictory. Hence, further research is needed regarding this practice.
\end{abstract}

Breast Feeding; Child Development; Child; Growth

\section{Resumen}

Se realizó una revisión sistemática para estudiar la prevalencia mundial de la lactancia materna durante dos o más años y sus efectos sobre el crecimiento y desarrollo infantil. Se consultaron las bases MEDLINE y LILACS sin restricciones de idioma o tiempo, obteniendo 3.561 títulos. Fueron leídos todos los títulos, 453 resúmenes y 49 artículos. Los artículos sobre lactancia materna $\geq$ 2 años fueron incluidos. El análisis fue realizado con 19 artículos que cumplieron los criterios de inclusión. Se calculó una prevalencia combinada de lactancia materna a los dos años de edad de un 33\% (IC95\%: 0,23; 0,42). Se observó una tendencia creciente de lactancia materna durante dos o más años en las últimas décadas en el sur de Asia. Los seis estudios que analizaron los efectos de la lactancia materna durante dos años o más sobre el crecimiento presentaron resultados contradictorios. No se encontró asociación con el desarrollo infantil. Se concluye que las evidencias de efectos a medio plazo de la lactancia materna durante dos o más años son escasas y contradictorias. Se requieren estudios adicionales sobre esta práctica.

Lactancia Materna; Desarrollo Infantil; Niño; Crecimiento 


\section{Background}

The recommendation to continue breastfeeding up to two years of age or beyond was presented under the Innocenti Declaration made by the World Health Organization (WHO) and the United Nations Children's Fund (UNICEF) 1 in 1990. However, evidence that supports the promotion of breastfeeding up to two years of age or beyond remains scarce. In a review by Hill et al. published in 20042 , only one paragraph was dedicated to evidence regarding twelve types of family and community behavior identified by WHO and UNICEF as important practices that constitute good child care. According to these authors, the main argument for promoting breastfeeding up to two years of age or beyond is based on the fact that, during the second year of a child's life, breast milk is a possible key source of vitamin A, calcium and proteins and provides protection against infectious agents 2 .

Surveys such as the Demographic and Health Survey (DHS - http://www.measuredhs.com/ aboutdhs, accessed on 30/Jul/2011) conducted by the Opinion Research Corporation Macro International (ORC Macro) and the World Breastfeeding Trends Initiative (WBTi - http:// worldbreastfeedingtrends.org, accessed on 30/ Jul/2011) organized by the International Baby Food Action Network (IBFAN), that assessed the state of breastfeeding in 33 different countries), provide a comparison between the duration of breastfeeding in different countries. After analyzing findings of the DHS in 37 countries in 1999, Haggerty \& Rutstein 3 found a continued increase in the percentage of 20 to 23-month old children still breastfeeding. According to a 2010 IBFAN report, only six out of 33 countries achieved median breastfeeding duration of 23-24 months or beyond: Bhutan and Malawi (23 months), India (24 months), Nepal (30 months), Bangladesh (32.8 months), and Sri Lanka (33 months). Few studies exist on the maternal characteristics related to breastfeeding up to two years of age or beyond. In India, living in a rural area and maternal unemployment were found to be associated with longer breastfeeding duration 4. In Brazil, mothers staying at home with their children during the first six months of life, not using a pacifier, and the later introduction of water, teas or other types of milk were variables associated with breastfeeding up to two years of age or beyond 5 .

Several authors have observed that breastfeeding duration is associated with a number of benefits in childhood and adult life. Horta et al. 6 evaluated the long-term effects of breastfeeding on adult health, excluding studies with a limited effect on childhood. Using a meta-analysis of overweight and obesity, these authors found that these factors were less frequent in individuals who had been breastfed. However, the breastfeeding period differed in each study ${ }^{6}$. Other authors, such as Labayen et al. 7 , observed better performance in ergometric tests conducted with children and teenagers that exclusively breastfed for longer periods of time in the first months of life. In a study of an Australian cohort, Oddy et al. 8 observed that breastfeeding for six months or more was associated with a lower frequency of psychological internalization and externalizing problems in children and adolescents. Victoria et al. 9 found that male adolescents who had been breastfed for more than nine months showed a school advantage of 0.5-0.8 years in comparison with those who had been breastfed for less than a month. In contrast, Kramer et al. ${ }^{10}$, in a randomized clinical trial conducted in Belarus, did not find any association between breastfeeding duration and child behavior.

WHO recommends that breastfeeding should continue for two years or more without accurately establishing a maximum duration for breastfeeding. In addition, there is insufficient evidence on the advantages and disadvantages of continuing breastfeeding after two years and the main medium-term effects of this practice are yet to be described. Hence, this article has the following aims: (1) describe the global prevalence of breastfeeding up to two years of age or beyond and the global trends in prevalence rates over the past three decades; and (2) conduct a systematic literature review on the medium-term effects of breastfeeding up to two years of age or beyond on two crucial aspects of child health: growth and development.

\section{Methods}

Based on evidence and international consensus, this study considers optimal breastfeeding as exclusive breastfeeding of infants during the first six months of life and continued breastfeeding up to two years of age or beyond 1,11.

Searches were made of the MEDLINE and LILACS databases without any language or date restrictions using the following keywords and their combinations: breastfeeding, breast feeding, prolong, continu, exten, sustain, long-t, protect, rate, prevalence study, survey, growth, and child development. To complete truncated words, the symbol $(*)$ was used for MEDLINE and \$ on LILACS. For both databases, results were restricted to the population under 18 years of age. To ensure a thorough review, the reference lists of all identified studies were reviewed. 
With regard to prevalence of breastfeeding up to two years of age or beyond, the search strategy retrieved 1,564 titles from MEDLINE and 28 from LILACS. After reading these titles, a total of 253 abstracts were selected for analysis (241 from MEDLINE and 12 from LILACS), of which 31 articles were read (26 from MEDLINE and 5 from LILACS). The titles and abstracts were screened to select articles related to the prevalence of prolonged breastfeeding, regardless of whether or not the exact duration was specified. At this stage, titles and abstracts describing an obviously shorter duration of breastfeeding (such as neonatal breastfeeding or perinatalrelated intervention) were excluded. To be included in this review, the selected articles had to describe breastfeeding up to two years of age or beyond throughout the whole text. Finally, 11 articles were chosen (10 from MEDLINE and 1 from LILACS) and evaluated according to Loney's guidelines, an instrument designed to assess the quality of prevalence studies 12 . The validity, applicability and interpretation of the results were scored based on eight criteria, with a maximum possible score of eight. Of the 11 articles evaluated, three received a score of $513,14,15$, six received a score of $63,16,17,18,19,20,21$ and two studies were given a score of 721,22 . The scores and main characteristics of these articles are shown in Table 1. The data obtained from these eleven selected articles was inputted into the Stata software version 12.1 (Stata Corp., College Station, USA) in order to calculate the combined prevalence through a random effects meta-analysis using the metan command (Figure 1). A random effects model, as opposed to a fixed effects model, was chosen because there was evidence of heterogeneity between studies ( $\mathrm{x}^{2}$ for heterogeneity $\mathrm{p}<$ 0.001). Other information sources were searched for breastfeeding prevalence, such as the ORC Macro DHS survey and the IBFANWBTi initiative (http://www.measuredhs.com/aboutdhs; http:// worldbreastfeedingtrends.org, accessed on 30/ Jul/2011). The ORC Macro STATcompiler website was also accessed, obtaining 43 DHS surveys related to breastfeeding prevalence in two-year-old children conducted in 17 different countries over the past 25 years.

In order to study the effects of breastfeeding up to two years of age or beyond on child growth and development, the search strategy retrieved 1,919 titles from MEDLINE and 50 from LILACS. Titles and abstracts describing an obviously shorter duration of breastfeeding, or studies with another research focus (such as maternal benefits, public policies or HIV transmission), were excluded. After reading the titles, 200 abstracts were chosen (187 from MEDLINE and 13 from
LILACS), and a detailed analysis of these abstracts reduced the number to 18 articles, each from MEDLINE. To be included in this review, the selected articles had to describe the effects of breastfeeding up to two years of age or beyond on child growth and development throughout the entire text. Ten articles were discarded using the inclusion criteria, giving a final total of eight articles. The methodological quality of the eight selected articles was scored according to a modified Downs and Black scale 23 . This scale allowed the authors to evaluate the selected articles by analyzing 19 characteristics (including reporting, validity, bias, confounding and power of the study), with a maximum possible score of 20 points. The average score of the eight articles was 15.1, with a minimum of 13 and maximum of 17. The main characteristics of these articles are described in Table 2.

\section{Results}

\section{Prevalence of breastfeeding up to two years of age or beyond and associated trends}

The combined prevalence of breastfeeding up to two years of age or beyond across the 11 studies was 33\% (95\%CI: 0.23; 0.42). However, significant heterogeneity of prevalence across different countries was observed. In certain countries, such as Iran, prevalence was approximately $1 \% 15$, whereas in Bangladesh, it was over $90 \% 13$.

The majority of the studies included in this review were conducted on the Asian continent, including one study from the Middle East 15, two from China 20,22, one in Indonesia 21, and three in Bangladesh 13,16,19. The sample also included one study from Africa (Sudan) 18 and one study presented data from 37 different countries ${ }^{3}$. Two studies were also conducted in America (Brazil and the Dominican Republic) 14,17.

Prevalence of breastfeeding up to two years of age or beyond over the last three decades was highest in the Asian continent. Studies carried out in the region of Matlab, Bangladesh, in the 1980s indicate that the median duration of breastfeeding was almost 30 months 13,16. In Bangladesh, Mulder-Sibanda 19 also found a $44.6 \%$ prevalence of breastfeeding between the first 24 and 35 months of life. In Jakarta, Indonesia, the findings of two studies regarding eating habits in 1976 and 198321 showed that the prevalence of breastfeeding between the first 14.4 and 19.8 months increased between 1976 and 1983 21. In central China, Taren and Chen reported a $16 \%$ prevalence of breastfeeding up to the first 24 months of life in the region of Hubei 20. Dang et 
Table 1

Characteristics of the 11 articles selected for the systematic review. Prevalence of breastfeeding up to two years of age or beyond, over the last 30 years.

\begin{tabular}{|c|c|c|c|c|c|c|c|c|c|}
\hline Study (year) & Setting & $\begin{array}{l}\text { Sample } \\
\text { size (n) }\end{array}$ & $\begin{array}{l}\text { Sample } \\
\text { design }\end{array}$ & $\begin{array}{l}\text { Sampling } \\
\text { frame }\end{array}$ & Measures & $\begin{array}{l}\text { Unbiased } \\
\text { assessors }\end{array}$ & $\begin{array}{c}\text { Response } \\
\text { rate and } \\
\text { refusals }\end{array}$ & $\begin{array}{l}\text { Prevalence } \\
\text { rates Bf } 2 y+\end{array}$ & $\begin{array}{l}\text { Score and } \\
\text { limitations }\end{array}$ \\
\hline \multicolumn{10}{|l|}{ Asia } \\
\hline $\begin{array}{l}\text { Huffman et al. } \\
(1980) 13\end{array}$ & $\begin{array}{c}\text { Matlab, Ban- } \\
\text { gladesh }\end{array}$ & 1,419 & $\begin{array}{c}\text { Cross- } \\
\text { sectional }\end{array}$ & $\begin{array}{c}\text { Restricted to } \\
\text { children }<3 \\
\text { years of age } \\
\text { in the rural } \\
\text { area }\end{array}$ & $\begin{array}{l}\text { Anthropometrics } \\
\text { survey of } \\
\text { morbidity, diet, } \\
\text { pregnancy, } \\
\text { contraception } \\
\text { and } \\
\text { breastfeeding }\end{array}$ & Yes & $57 \%$ & $\begin{array}{c}91 \% \\
\text { Without Cl }\end{array}$ & $\begin{array}{c}\text { Score } 5 \\
\text { Restricted } \\
\text { population } \\
\text { Low response } \\
\text { rate } \\
\text { Without } \mathrm{Cl}\end{array}$ \\
\hline $\begin{array}{l}\text { Briend et al. } \\
\text { (1988) } 16\end{array}$ & $\begin{array}{c}\text { Matlab, } \\
\text { Bangladesh }\end{array}$ & 27,675 & $\begin{array}{l}\text { Cross- } \\
\text { sectional }\end{array}$ & $\begin{array}{c}\text { Restricted } \\
\text { to children } \\
\text { between } \\
12 \text { and } 36 \\
\text { months of } \\
\text { age in rural } \\
\text { districts of } \\
\text { Matlab }\end{array}$ & $\begin{array}{l}\text { Anthropometrics } \\
\text { survey on } \\
\text { diarrheic } \\
\text { infections and } \\
\text { survival }\end{array}$ & Yes & $100 \%$ & $\begin{array}{c}74 \% \\
\text { Without Cl }\end{array}$ & $\begin{array}{l}\text { Score } 6 \\
\text { Restricted } \\
\text { population } \\
\text { Without Cl }\end{array}$ \\
\hline $\begin{array}{l}\text { Mulder-Sibanda } \\
\text { (1999) } 19\end{array}$ & Bangladesh & 5,502 & $\begin{array}{c}\text { Cross- } \\
\text { sectional }\end{array}$ & $\begin{array}{c}\text { Restricted } \\
\text { to } 5,502 \\
\text { children } \\
\text { between } \\
6 \text { and } 71 \\
\text { months of } \\
\text { age in urban } \\
\text { and rural } \\
\text { areas }\end{array}$ & $\begin{array}{l}\text { Diarrhea records } \\
\text { Nutritional survey }\end{array}$ & Yes & $>95 \%$ & $\begin{array}{c}44.6 \% \\
\text { Without Cl }\end{array}$ & $\begin{array}{l}\text { Score } 6 \\
\text { Restricted } \\
\text { population } \\
\text { Without Cl }\end{array}$ \\
\hline $\begin{array}{l}\text { Joesoef et al. } \\
\text { (1989) } 21\end{array}$ & Indonesia & 1,617 & $\begin{array}{l}\text { Cross- } \\
\text { sectional }\end{array}$ & $\begin{array}{c}608 \text { children } \\
<3 \text { years of } \\
\text { age:1976 } \\
1,009 \\
\text { children } \\
<3 \text { years of } \\
\text { age:1983 }\end{array}$ & $\begin{array}{c}\text { National survey } \\
\text { of Indonesian } \\
\text { households, } 1976 \\
\text { and } 1983\end{array}$ & Yes & $>90 \%$ & $\begin{array}{c}27 \% 1976 \\
43 \% 1983 \\
\text { Without Cl }\end{array}$ & $\begin{array}{c}\text { Score } 7 \\
\text { Without Cl }\end{array}$ \\
\hline $\begin{array}{l}\text { Taren \& Chen } \\
\text { (1993) } 20\end{array}$ & Hubei, China & 2,148 & $\begin{array}{l}\text { Cross- } \\
\text { sectional }\end{array}$ & $\begin{array}{l}\text { Restricted } \\
\text { to } 2,148 \\
\text { children } \\
\text { between } \\
12 \text { and } \\
47 \text { months } \\
\text { in the Hubei } \\
\text { province }\end{array}$ & $\begin{array}{l}\text { Anthropometrics } \\
\text { survey of } \\
\text { supplementary } \\
\text { food, order of } \\
\text { birth, infections, } \\
\text { weight at } \\
\text { birth, father's } \\
\text { occupation, } \\
\text { mother's } \\
\text { education }\end{array}$ & Yes & $\geq 95 \%$ & $\begin{array}{c}16 \% \\
\text { Without Cl }\end{array}$ & $\begin{array}{c}\text { Score } 6 \\
\text { Restricted } \\
\text { population } \\
\text { Without Cl }\end{array}$ \\
\hline
\end{tabular}

(continues) 
Table 1 (continued)

\begin{tabular}{|c|c|c|c|c|c|c|c|c|c|}
\hline Study (year) & Setting & $\begin{array}{l}\text { Sample } \\
\text { size (n) }\end{array}$ & $\begin{array}{l}\text { Sample } \\
\text { design }\end{array}$ & $\begin{array}{l}\text { Sampling } \\
\text { frame }\end{array}$ & Measures & $\begin{array}{l}\text { Unbiased } \\
\text { assessors }\end{array}$ & $\begin{array}{c}\text { Response } \\
\text { rate and } \\
\text { refusals }\end{array}$ & $\begin{array}{c}\text { Prevalence } \\
\text { rates Bf } 2 y+\end{array}$ & $\begin{array}{l}\text { Score and } \\
\text { limitations }\end{array}$ \\
\hline \multicolumn{10}{|l|}{ Asia } \\
\hline $\begin{array}{l}\text { Dang et al. } \\
\text { (2009) } 22\end{array}$ & Tibet, China & 3,081 & $\begin{array}{l}\text { Cross- } \\
\text { sectional }\end{array}$ & $\begin{aligned} & 1,655 \\
& \text { children } \\
&< 3 \text { years }\end{aligned}$ & $\begin{array}{l}\text { Survey of mother } \\
\text { and child health } \\
\text { Registration of } \\
\text { the altitude of } \\
\text { urban or rural } \\
\text { dwelling place }\end{array}$ & Yes & $100 \%$ & $\begin{array}{c}55 \% \text { urban } \\
66 \% \text { rural } \\
\text { Without } \mathrm{Cl}\end{array}$ & $\begin{array}{c}\text { Score } 7 \\
\text { Without Cl }\end{array}$ \\
\hline $\begin{array}{l}\text { Rakhshani \& Mo- } \\
\text { hammadi } \\
\text { (2009) } 15\end{array}$ & Iran & 1,264 & Longitudinal & $\begin{array}{c}\text { Restricted } \\
\text { to } 1,264 \\
\text { medical } \\
\text { records of } \\
\text { children < } 3 \\
\text { years of age } \\
\text { in } 6 \text { health } \\
\text { centers } \\
\text { (Zabol } \\
\text { region) }\end{array}$ & $\begin{array}{l}\text { Historic cohort } \\
\text { study health } \\
\text { records and } \\
\text { supplementary } \\
\text { food }\end{array}$ & Yes & Not defined & $\begin{array}{c}1 \% \\
\text { without } \mathrm{Cl}\end{array}$ & $\begin{array}{c}\text { Score } 5 \\
\text { Restricted } \\
\text { population } \\
\text { Refusals } \\
\text { without } \\
\text { description } \\
\text { Without Cl }\end{array}$ \\
\hline \multicolumn{10}{|l|}{ Africa } \\
\hline $\begin{array}{l}\text { Fawzi et al. } \\
(1998) 18\end{array}$ & $\begin{array}{l}\text { Rural area, } \\
\text { Sudan }\end{array}$ & 28,753 & Longitudinal & $\begin{array}{c}\text { Restricted } \\
\text { to } 28,753 \\
\text { children }<3 \\
\text { years of age } \\
\text { from rural } \\
\text { areas }\end{array}$ & $\begin{array}{l}\text { Cohort study } \\
\text { Anthropometrics } \\
\text { Nutritional } \\
\text { Survey }\end{array}$ & Yes & $>84 \%$ & $\begin{array}{c}27 \% \\
\text { without Cl }\end{array}$ & $\begin{array}{c}\text { Score } 6 \\
\text { Restricted } \\
\text { population } \\
\text { Without Cl }\end{array}$ \\
\hline \multicolumn{10}{|l|}{ America } \\
\hline $\begin{array}{l}\text { Bautista } \\
\text { (1996) } 17\end{array}$ & $\begin{array}{c}\text { Dominican } \\
\text { Republic }\end{array}$ & 1,984 & $\begin{array}{l}\text { Cross-section- } \\
\text { al concurrent } \\
\text { cohort study }\end{array}$ & $\begin{array}{c}1984 \\
\text { children }<3 \\
\text { years }\end{array}$ & $\begin{array}{l}\text { Home survey of } \\
\text { demographics } \\
\text { and family health }\end{array}$ & Yes & $\begin{array}{c}\text { 83\% DHS- } \\
1991 \\
\text { refusals }\end{array}$ & $\begin{array}{c}8.6 \% \\
\text { without Cl }\end{array}$ & $\begin{array}{c}\text { Score } 6 \\
\text { Refusals } \\
\text { without } \\
\text { description } \\
\text { Without Cl }\end{array}$ \\
\hline $\begin{array}{l}\text { Simon et al. } \\
(2009) 14\end{array}$ & Brazil & 566 & $\begin{array}{l}\text { Cross-sec- } \\
\text { tional }\end{array}$ & $\begin{array}{l}\text { Restricted to } \\
809 \text { children } \\
\text { between } 2 \\
\text { and } 6 \text { years } \\
\text { of age from } \\
7 \text { private } \\
\text { schools in } \\
\text { São Paulo. }\end{array}$ & $\begin{array}{c}\text { Mothers or } \\
\text { legal guardians } \\
\text { interviewed on } \\
\text { nutritional status } \\
\text { and diet during } \\
\text { childhood }\end{array}$ & Yes & $\begin{array}{c}70 \% \text { of } \\
\text { interviews } \\
\text { refusals }\end{array}$ & $\begin{array}{c}5.5 \% \\
\text { without Cl }\end{array}$ & $\begin{array}{c}\text { Score } 5 \\
\text { Restricted } \\
\text { population } \\
\text { Refusals } \\
\text { without } \\
\text { description } \\
\text { Without Cl }\end{array}$ \\
\hline \multicolumn{10}{|l|}{ Worldwide } \\
\hline $\begin{array}{l}\text { Haggerty \& Rust- } \\
\text { stein (1999) } 3\end{array}$ & World & 254,737 & $\begin{array}{l}\text { Cross- } \\
\text { sectional } \\
\text { DHS survey }\end{array}$ & $\begin{array}{c}\text { Children < } \\
\text { 3years of } \\
\text { age in } 37 \\
\text { countries in } \\
4 \text { regions }\end{array}$ & $\begin{array}{l}\text { Home survey of } \\
\text { demographics } \\
\text { and family health }\end{array}$ & Yes & Not defined & $\begin{array}{c}\text { 15.6\% Sub- } \\
\text { Saharan Africa } \\
5.4 \% \text { North } \\
\text { and East } \\
\text { Africa } \\
33.8 \% \text { Asia } \\
9.3 \% \text { Latin } \\
\text { America } \\
\text { without } \mathrm{Cl}\end{array}$ & $\begin{array}{c}\text { Score } 6 \\
\text { Refusals } \\
\text { without } \\
\text { description } \\
\text { Without Cl }\end{array}$ \\
\hline
\end{tabular}

Bf2y+: breastfeeding up to two years of age or beyond; Cl: confidence interval; score according to Loney's guidelines 12 . 


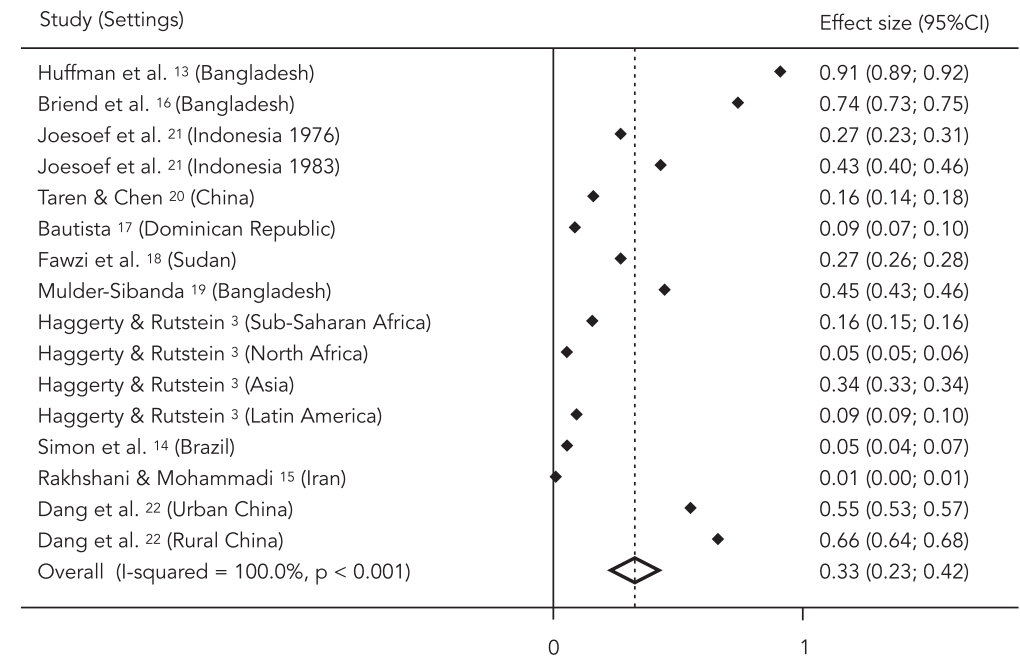

95\% $\mathrm{Cl}: 95 \%$ confidence interval.

al. 22 also conducted a health survey in Tibet and found a prevalence of breastfeeding up to the first 24 months of life of $55 \%$ in urban areas and $66 \%$ in rural areas 22. In contrast, Rakhshani \& Mohammadi 15 reported that prevalence of breastfeeding up to this age in Iran was nearly $1 \%$.

Furthermore, a cohort study with 28,753 children under three years of age carried out by Fawzi et al. 18 in 1998 showed a prevalence of $27 \%$ in rural regions of Sudan. A study conducted in the Dominican Republic found that the median duration of breastfeeding was seven months, while prevalence of breastfeeding up to two years of age was less than $9 \%$ 17. In Brazil, unpublished data from the 2004 Pelotas Birth Cohort Study showed a $20 \%$ prevalence of breastfeeding up to two years of age. In contrast, Simon et al. 14 reported a $5.5 \%$ prevalence of breastfeeding in the urban São Paulo in 2009.

In 1999, Haggerty \& Rutstein 3 compared breastfeeding prevalence reported in DHS surveys carried out in 37 countries. Prevalence of breastfeeding between the first 24 and 35 months of life was $15.6 \%$ in Sub-Saharan Africa, $5.4 \%$ in North and East Africa, 33.8\% in Asia, and 9.3\% in Latin America and the Caribbean region.

Figure 2 shows the results of breastfeeding prevalence up to 24-25 months in 43 DHS surveys conducted in 17 countries grouped into three regions (South Asia, South America and
Southern Africa) using data from the ORC Macro STATCompiler website (http:/ / www.measuredhs. com/aboutdhs, accessed on 30/Jul/2011). Results show a growing trend in prevalence of breastfeeding up to two years of age, especially in South Asia (Linear trend test, $\mathrm{p}=0.04$ ). This trend is less pronounced in the southern regions of Africa $(\mathrm{p}=$ 0.662) and in South America ( $\mathrm{p}=0.081)$.

In summary, breastfeeding prevalence is particularly heterogeneous across countries and the majority of the studies evaluated were carried out in South Asia. The lowest prevalence rate was observed in Iran, and the highest in Bangladesh. It was also possible to observe a trend towards an increase in breastfeeding up to two years of age or beyond in South Asia.

\section{Medium-term effects of breastfeeding up to two years of age or beyond on child growth and development}

Six articles evaluated the effects of breastfeeding up to two years of age or beyond on different aspects of child growth and two articles evaluated effects on child development. The main characteristics of these eight articles are shown in Table 2. Five of these articles studied the effects on anthropometric measurements and indices, such as weight, height and z-score for weight/ age, weight/height and height/age 18,20,24,25,26. 
Figure 2

Increase in breastfeeding prevalence at 24-25 months.

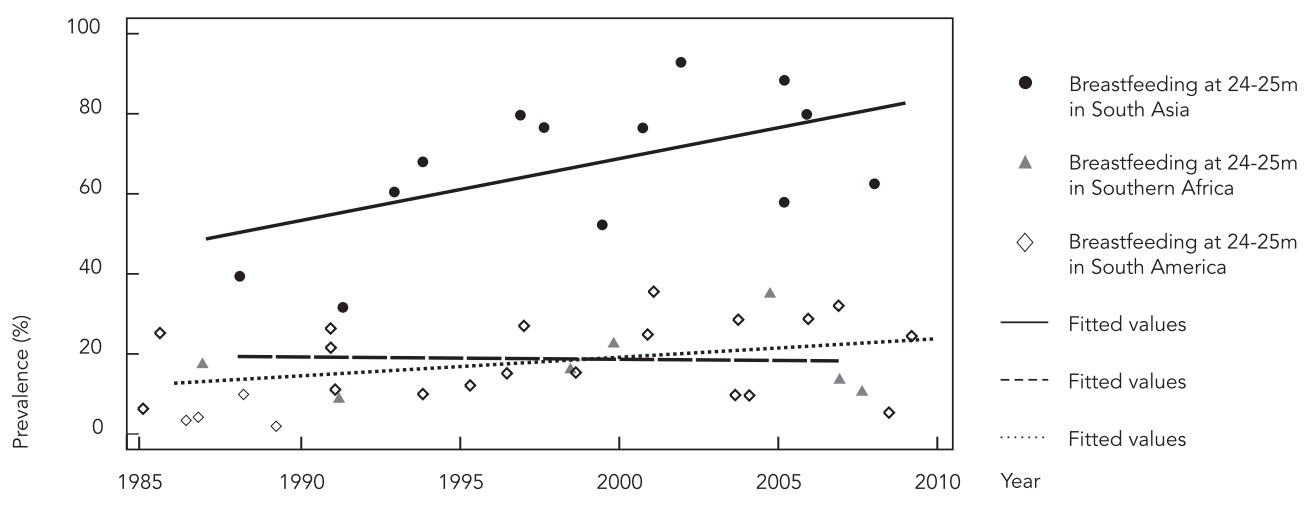

Source: DHS-Stat Compiler.

Table 2

Characteristics of the eight selected articles for the systematic review. Effects of breastfeeding up to two years of age or more on child growth and development.

\begin{tabular}{|c|c|c|c|c|c|c|}
\hline $\begin{array}{l}\text { Author } \\
\text { (year) }\end{array}$ & Design & $\begin{array}{l}\text { Country, sample, } \\
\text { study (period) }\end{array}$ & Exposure & Main outcome & Results & Score \\
\hline $\begin{array}{l}\text { Ng'andu \& } \\
\text { Watts } \\
(1990) 26\end{array}$ & $\begin{array}{l}\text { Cross- } \\
\text { sectional }\end{array}$ & $\begin{array}{c}\text { Zambia, } 376 \\
\text { children under age } \\
5(1984-1986)\end{array}$ & $\begin{array}{l}\text { Breastfeeding up } \\
\text { to } 2 \text { years of age } \\
\text { or beyond }\end{array}$ & $\begin{array}{c}\text { Growth measured using z-score } \\
\text { height/age, weight/age, } \\
\text { weight/height }\end{array}$ & $\begin{array}{l}\text { No differences were detected } \\
\text { in the anthropometric indices } \\
\text { between children breastfed up } \\
\text { to } 2 \text { years of age or beyond } \\
\text { compared with children } \\
\text { breastfed for less than } 2 \text { years }\end{array}$ & 14 \\
\hline $\begin{array}{l}\text { Fawzi et al. } \\
\text { (1998) } 18\end{array}$ & $\begin{array}{l}\text { Cohort } \\
\text { study }\end{array}$ & $\begin{array}{l}\text { Sudan, } 28,753 \\
\text { children }<36 \mathrm{~m} \\
(1988-1990)\end{array}$ & $\begin{array}{l}\text { Breastfeeding up } \\
\text { to } 2 \text { years of age } \\
\text { or beyond }\end{array}$ & $\begin{array}{l}\text { Growth measured as } \\
\text { weight in grams }\end{array}$ & $\begin{array}{l}\text { Children from poor households } \\
\text { breastfed up to two years of } \\
\text { age or beyond showed lower } \\
\text { weight than those who were } \\
\text { weaned }(-205 \mathrm{~g}, 95 \% \mathrm{Cl} \text { : }-279 ; \\
-131)\end{array}$ & 16 \\
\hline $\begin{array}{l}\text { Simondon } \\
\text { \& Simondon } \\
(1998) 24\end{array}$ & $\begin{array}{l}\text { Cross- } \\
\text { sectional }\end{array}$ & $\begin{array}{l}\text { Senegal, 4,515 } \\
\text { children under } 3 \\
\text { years of age } \\
(1989-1996)\end{array}$ & $\begin{array}{l}\text { Growth measured } \\
\text { with z-score } \\
\text { height/age, } \\
\text { weight/age }\end{array}$ & $\begin{array}{l}\text { Duration of breastfeeding } \\
\text { in months }\end{array}$ & $\begin{array}{l}\text { Those children with a z-score } \\
\text { for height/age below -2 at } \\
\text { 9-10 months had a median } \\
\text { duration of breastfeeding of } \\
25 \text { months. The children with a } \\
\text { z-score for height/age between } \\
-2 \text { and } 1 \text { at } 9-10 \text { months of } \\
\text { age had a median duration of } \\
\text { breastfeeding of } 24.1 \text { months }\end{array}$ & 17 \\
\hline
\end{tabular}

(continues) 
Table 2 (continued)

\begin{tabular}{|c|c|c|c|c|c|c|}
\hline $\begin{array}{l}\text { Author } \\
\text { (year) }\end{array}$ & Design & $\begin{array}{l}\text { Country, sample, } \\
\text { study (period) }\end{array}$ & Exposure & Main outcome & Results & Score \\
\hline $\begin{array}{l}\text { Tarem \& } \\
\text { Chen } \\
\text { (1993) } 20\end{array}$ & $\begin{array}{l}\text { Cross- } \\
\text { sectional }\end{array}$ & $\begin{array}{l}\text { China, 2,148 12- } \\
\text { 47-month-old } \\
\text { children } \\
\text { (1989-1990) }\end{array}$ & $\begin{array}{l}\text { Breastfeeding up } \\
\text { to } 2 \text { years of age } \\
\text { or beyond }\end{array}$ & $\begin{array}{c}\text { Growth measured using z-score } \\
\text { height/age, weight/age, } \\
\text { weight/height }\end{array}$ & $\begin{array}{l}\text { Children who were breastfed } \\
\text { for } 2 \text { years or more had better } \\
\text { anthropometric indices than } \\
\text { children who were breastfed for } \\
\text { less than } 12 \text { months: } \\
\text { Z score height/age: }-1.50 \pm \\
0.06 \text { vs. }-1.76 \pm 0.08 \\
\text { Z score weight/age: }-1.22 \pm \\
0.05 \text { vs. }-1.38 \pm 0.06 \\
\text { Z score weight/height: }-0.34 \pm \\
0.05 \text { vs. }-0.05 \pm 0.04\end{array}$ & 16 \\
\hline $\begin{array}{l}\text { Simondon et } \\
\text { al. (2001) } 25\end{array}$ & $\begin{array}{l}\text { Cohort } \\
\text { study }\end{array}$ & $\begin{array}{c}\text { Senegal, } 443 \\
\text { children followed } \\
\text { up for } 6 \text { months, } \\
\text { in the } 2 \text { nd and } 3 \text { rd } \\
\text { year of life } \\
\text { (1995-1998) }\end{array}$ & $\begin{array}{l}\text { Breastfeeding up } \\
\text { to } 2 \text { years of age } \\
\text { or beyond }\end{array}$ & $\begin{array}{l}\text { 6-month growth measured } \\
\text { as height in } \mathrm{cm}\end{array}$ & $\begin{array}{l}\text { Children who were breastfed } \\
\text { for more than two years had } \\
\text { higher growth at } 6 \text { months than } \\
\text { children who had already been } \\
\text { weaned }(0.7 \mathrm{~cm}+0.3 ; \mathrm{p}<0.05)\end{array}$ & 13 \\
\hline $\begin{array}{l}\text { Simon et al. } \\
(2009) 14\end{array}$ & $\begin{array}{l}\text { Cross- } \\
\text { sectional }\end{array}$ & $\begin{array}{l}\text { Brazil, } 566 \text { children } \\
\text { between } 2 \text { and } 6 \\
\text { years of age from } \\
7 \text { private schools in } \\
\text { São Paulo (2004- } \\
\text { 2005) }\end{array}$ & $\begin{array}{l}\text { Breastfeeding up } \\
\text { to } 2 \text { years of age } \\
\text { or beyond }\end{array}$ & $\begin{array}{l}\text { Overweight/obesity measured } \\
\text { with BMI curves } \% \geq 85\end{array}$ & $\begin{array}{l}\text { Children who were breastfed } \\
\text { for two years or more showed } \\
\text { lower overweight/obesity than } \\
\text { children who were breastfeed } \\
\text { from } 0 \text { to } 6 \text { months }(9.7 \% \text { vs. } \\
\qquad 35 \%, p=0.02)\end{array}$ & 13 \\
\hline $\begin{array}{l}\text { Daniels \& } \\
\text { Adair } \\
(2005) 27\end{array}$ & $\begin{array}{l}\text { Cohort } \\
\text { study }\end{array}$ & $\begin{array}{l}\text { Philippines, } 1,979 \\
\text { children followed } \\
\text { up from birth } \\
\text { through to middle } \\
\text { childhood (1983- } \\
\text { 1995) }\end{array}$ & $\begin{array}{l}\text { Breastfeeding up } \\
\text { to } 2 \text { years of age } \\
\text { or beyond }\end{array}$ & $\begin{array}{c}\text { Cognitive ability assessed at } \\
\text { ages } 8.5 \text { and } 11.5 \text { years with } \\
\text { the Philippines Nonverbal } \\
\text { Intelligence Test }\end{array}$ & $\begin{array}{l}\text { At } 8.5 \text { years, no effect on } \\
\text { cognitive ability score was } \\
\text { observed in children who were } \\
\text { breastfeed for } 24 \text { months or } \\
\text { more }(49.4, \mathrm{SD}=11.8, \mathrm{n}= \\
270) \text {, compared with children } \\
\text { breastfeed }<6 \text { months ( } 53.7 \text {, } \\
\text { SD } 13.4, \mathrm{n}=459)\end{array}$ & 15 \\
\hline $\begin{array}{l}\text { Duazo et al. } \\
(2010) 28\end{array}$ & $\begin{array}{l}\text { Cohort } \\
\text { study }\end{array}$ & $\begin{array}{l}\text { Philippines, } 2,752 \\
\text { children aged 5-6 } \\
\text { years (2002-2005) }\end{array}$ & $\begin{array}{l}\text { Breastfeeding up } \\
\text { to } 2 \text { years of age } \\
\text { or beyond }\end{array}$ & $\begin{array}{c}\text { Psychosocial development } \\
\text { assessed with the Philippines } \\
\text { Revised Early Childhood } \\
\text { Development Checklist }\end{array}$ & $\begin{array}{l}\text { No effect was observed in } \\
\text { the psychosocial develop- } \\
\text { ment score amongst children } \\
\text { breastfed for more than } 2 \text { years, } \\
\text { compared with peers who were } \\
\text { breastfed for less than } 6 \text { months }\end{array}$ & 17 \\
\hline
\end{tabular}

BF: breastfeeding; BMI: body mass index; Cl: confidence interval; Q: quartile; score according to Downs guidelines 23 .

One article analyzed the effects of breastfeeding up to two years of age or beyond on overweight/ obesity in childhood defined as having a body mass index (BMI) $\geq 85 \%$ for age, according to the 2000 Centers for Disease Control and Prevention (CDC) growth charts 14. A further article assessed the effects of breastfeeding on cognitive ability at 8.5 and 11.5 years of age using the Philippines Nonverbal Intelligence Test 27 . Finally, one article also assessed psychosocial development at five and six years of age using the Philippines Revised Early Childhood Development Checklist 28.

Three articles reported a negative or null effect of breastfeeding up to two years of age or beyond on different aspects of growth.

In 1990, Ng'andu \& Watts 26 , in a transversal study conducted with 438 children between two and five years of age from a community in the urban periphery of Lusaka in Zambia, reported that prevalence of breastfeeding up to 
two years of age or beyond was $13.3 \%$ and found no association between breastfeeding to this age and height/age, weight/age or weight/height zscores. No change was observed after controlling for possible confounding factors, such as child's age, previous diseases, maternal and paternal educational level, previous pregnancies, , and availability of water and sewage services.

Fawzi et al. 18, in a 1998 cohort study conducted with 28,753 children under three years of age living in five rural communities in north Sudan, observed that infants from poor households who were breastfed during the first two years of life had a lower weight than children who had been weaned (-205g, 95\%CI: -279; -131). This effect was lower in children from non-poor households (-38g, 95\%CI: -106 ; 30). Likewise, the weight of children breastfed up to two years of age or beyond whose mothers had a lower level of education was lower than that of children breastfed to the same age whose mothers had a higher level of education (-133, 95\%CI: -193; -74 versus -88g, 95\%CI: -179 ; 4 , respectively). These findings allowed the authors to conclude that the association between breastfeeding up to two years of age or beyond and nutritional status was modified by the socioeconomic status and maternal educational level.

In a cross-sectional study of a sample of 4,515 children aged 18 to 36 months in the region of Nikhar, Senegal, published in 1998, Simondon \& Simondon 24 observed that children with higher height/age deficits at 9-10 months of age showed longer median duration of breastfeeding. The median duration of breastfeeding was 25.0 months for $\mathrm{z}$-score $<-2,24.1$ months for $\mathrm{z}$-score from -2 to $-1,23.4$ months for $\mathrm{Z}$-scores from - 1 to 0 , and 22.7 month for $\mathrm{z}$-scores above 0 .

Three of the articles showed favorable effects of breastfeeding up to two years of age or beyond on child growth. The first, published in 1993 by Taren \& Chen 20 , described a transversal study using a sample of 2,148 children between the ages of 12 to 47 months, conducted in the rural province of Hubei, China. The authors observed that those children who had been breastfed for two years or more had better anthropometric indices than those children who had been breastfed for less than twelve months (z-score for height/age: -1.50 ; $\mathrm{SD}=0.06$ vs. -1.76 ; $\mathrm{SD}=$ 0.08 ; $\mathrm{Z}$-score for weight/age: -1.22 ; $\mathrm{SD}=0.05$ vs. -1.38; SD = 0.06; z-score for weight/height: -0.34 ; $\mathrm{SD}=0.05$ vs. $-0.05 ; \mathrm{SD}=0.04$, in children who were breastfed for more than two years in comparison with those who had breastfeed for less than a year, respectively).

Another article by Simondon et al. 25 regarding a cohort study carried out in 2001 with 443 children under the age of three in the Senegalese region of Niakhar, observed that the children who had been breastfed for two years or more had a greater six-month increase in height in comparison with children who had already been weaned $(0.7 \mathrm{~cm} \mathrm{SD}=0.3 ; \mathrm{p}<0.05)$. Socioeconomic level, interpreted according to type of dwelling place (cement or clay), was a key modifying factor for the association between breastfeeding and height. In contrast to non-poor households, in poor households, breastfeeding up to two years of age or beyond was associated with better growth.

Research carried out in 2009 by Simon et al. 14 , in which a transversal study was conducted with 566 children aged two to six years in seven private schools in São Paulo, Brazil was the only study to evaluate the effects of breastfeeding up to two years of age or beyond on overweight/ obesity. These authors scored the category overweight/obesity, defined as a BMI $\geq 85$ using the 2000 CDC growth charts. This study showed that breastfeeding up to two years of age or beyond was a protective factor against overweight/ obesity. The frequency of overweight/obesity in children breastfed for two years or more was observed to be $9.7 \%$, compared to $35 \%$ ( $p=0.02$ ) amongst children who breastfed for zero to six months.

The following two articles reported a null effect of breastfeeding up to two years of age or beyond on cognitive ability and psychosocial development.

Daniels et al. 27 described data from a 1984 cohort study of children born in 1983 and 1984 in Metropolitan Cebu, Philippines. These authors assessed the relation between breastfeeding and cognitive ability using a validated nonverbal intelligence test of analytic and reasoning skills (Philippines Nonverbal Intelligence Test). Cognitive ability was assessed at ages 8.5 and 11.5 years by individuals unaware of their breastfeeding status. After controlling for confounding variables, scores were higher for infants that were breastfed for longer. However, this effect was less pronounced in children who were breastfed for more than 18 months. Daniels et al. observed that 9.5year-old children who were breastfed up to two years of age or beyond achieved similar cognitive ability test scores to those children breastfeed for less than six months (49.4; $\mathrm{SD}=11.8 ; \mathrm{n}=270$ vs. $53.7 ; \mathrm{SD}=13.4 ; \mathrm{n}=459$ ). Similar results were observed in the test scores of 11.5-year-old children $(p=0.446)$.

Duazo et al. 28 analyzed data from a cohort study of 2,752 children aged five to six years in the Philippines. Follow-ups were conducted at yearly intervals, with a total of four surveys completed 
by the end of the study in 2005. These authors assessed the effects of duration of breastfeeding on psychosocial development using a list of skills sequenced by age (Philippines Revised Early Childhood Development Checklist). Psychosocial development was assessed at ages five to six years in the final follow-up. Duration of breastfeeding was evaluated through maternal recall at each of the yearly follow-up surveys. After adjustment for confounders, these authors found that breastfeeding duration had a protective effect on future psychosocial development. However, this effect was not evident when children were breastfed for two years or more. At five years of age, children who were breastfed for two years or more obtained the same psychosocial development scores as those children breastfed for less than twelve months (1.54, 95\%CI: 20.49; 3.57 vs. 1.62 ; 95\%CI: 20.75; 3.99, p > 0.1). Similar results were observed in six-year-old children.

\section{Discussion}

This review shows that the combined prevalence of breastfeeding up to two years of age was 33\% (95\%CI: 0.23; 0.42). Evidence also indicates a trend towards an increase in prevalence of breastfeeding up to two years of age or beyond in the past three decades, especially in South Asia. In addition, this review identified eight studies that analyzed the medium-term effects of breastfeeding up to two years of age or beyond on child growth and development. However, these studies showed contradictory results.

The trend towards an increase in prevalence observed in South Asia could be partially attributed to a number of activities carried out by different organizations, such as the IBFAN, International Lactation Consultant Association (ILCA), La Leche League International, World Alliance for Breastfeeding Action (WABA), WHO and UNICEF, which have been acting as a network to promote breastfeeding for over 30 years. Policies, laws and initiatives, such as The International Code of Marketing of Breast Milk Substitutes and Mother and Baby-Friendly Hospital, in many countries also aim to protect, promote and support breastfeeding 29,30,31. However, the fact that these and other organizations also act in other regions of the world, suggests a variable influence on the duration of breastfeeding, probably determined by the existing conditions in the region where their activities are performed.

According to Cattaneo 32, women's role in the family and society, routine health services and the pressure exerted by the baby food industry are some of the factors that influence the changes observed in the past decades in several countries and societies regarding the practice and duration of breastfeeding. Certain types of behavior practiced by families in the first months of a baby's life have a protective effect on the duration of breastfeeding, such as sharing the same bed with the child. Santos et al. 33 found that $75 \%$ of children that were exclusively breastfed and who shared the same bed with their mother up to three years of age continued breastfeeding up to the age of 12 months, compared to $52 \%$ of children who did not share the same bed (adjusted RR $=0.63$; 95\%CI: 0.53; 0.75, p < 0.001).

Another alternative to support extended breastfeeding duration is personalized counseling ${ }^{34}$. Albernaz et al. 35 , in a blind, randomized intervention trial, evaluated the effects of counseling on 188 breastfeeding mothers. These authors detected that counseling regarding breastfeeding increased the duration of this practice, but failed to increase the volume of breast milk produced. A review of the Cochrane Library conducted by Britton et al. 36 including 34 studies from 14 countries and approximately 30,000 women, pointed out that professional support was effective in extending breastfeeding duration. It also revealed that non-professional support was more effective in prolonging exclusive breastfeeding duration.

In the United States, Kogan et al. 37 observed differences in the start and duration of breastfeeding across different states. These authors carried out a multilevel analysis of the effect of legislation on breastfeeding. Using a US national databank, they studied children aged six to 71 months in the period 1999 to 2003. The authors found that states of Alabama, Arizona, Arkansas, Colorado, Kansas, Kentucky, Massachusetts, Mississippi, Nebraska, North Dakota, Ohio, Oklahoma, Pennsylvania, South Carolina and West Virginia and the District of Columbia had no legal framework to support the practice of breastfeeding (such as exemption of public breastfeeding from indecency laws, provision of breastfeeding information after birth, and the right to take breaks at work to breastfeed or manually extract breast milk). These authors observed that children who lived in these states were less likely to be exclusively breastfed, compared to infants living in states with pro-breastfeeding legislation. Another example where pro-breastfeeding legislation extended the duration of breastfeeding was in Brazil, where diverse strategies have been gradually implemented (such as the Brazilian national breastfeeding program, the code of marketing of breast milk substitutes and the extension of maternity leave). These strategies contributed to a four-fold increase in median breastfeeding du- 
ration in this country since 1974 (2.5 months in 1974, 5.5 months in 1989, 7 months in 1996, and 14 months in 2006-2007) 38,39.

The increase in prevalence of breastfeeding up to two years of age and beyond observed in the past 30 years in South Asia can be attributed to the following factors: activities carried out by several international organizations, strategies implemented in health centers, control of advertising pressure through the creation of probreastfeeding laws and codes, and, possibly, to a greater social participation and acceptance of this practice. It is important to note however that these strategies implemented in other regions of the world have not led to an increase in prevalence of breastfeeding up to two years of age or beyond.

\section{Association between breastfeeding up to two years of age or beyond and child growth and development}

Eight articles were located that investigated the association between breastfeeding up to two years of age or beyond and child growth and development. With respect to child growth, the lack of publications and heterogeneous nature of studies on the benefits of extended breastfeeding have already been highlighted by Elsom \& Weaver 40 in their review of the effects of breastfeeding for more than twelve months published in 1999. This review included two longitudinal and eight transversal studies that analyzed the relationship between the duration of breastfeeding and results such as undernourishment or survival. The authors analyzed anthropometric indices (weight/height, weight/age, height/age) and their association with breastfeeding for more than a year in 33,375 children under five years of age. The authors were not able to make any definitive conclusions due to the presence of reverse causality in most of the selected studies. In another systematic review conducted by Horta et al. 6 , the duration of breastfeeding (variable between studies, from $>1$ to $>12$ months) was observed to be associated with lower blood pressure and total cholesterol values in adult life. The authors reported a publication cut-off and possible residual confusion in the results related to blood pressure. With respect to the association between breastfeeding and overweight/obesity, Horta et al. 6 found that the studies which controlled for confounding factors, such as economic status and paternal anthropometry, suggested the existence of an association between longer breastfeeding duration and low prevalence of obesity. These authors found a lack of homogeneity in the definitions of breastfeeding in many obser- vational studies and few studies conducted in low-income countries, thus limiting the study's conclusions.

Only two articles were found that studied the association between breastfeeding up to two years of age or beyond and child development; neither offered evidence of a causal association. Daniels \& Adair 27 and Duazo et al. 28, Oddy et al. 8 , Victora et al. 9 and Slykerman et al. 41 , all suggested that shorter breastfeeding duration may be associated with higher cognitive ability scores 27 , higher psychosocial development scores 28 , fewer internalization problems 8 , better school performance ${ }^{9}$ and better performance in IQ tests 41 . However, the association reported in these articles was not assessed as a breastfeeding duration of less than two years is beyond the scope of this review.

\section{A window of opportunity for breastfeeding up to two years of age or beyond}

The first 1,000 days of a child's life, i.e., the time between gestation and the first two postnatal years, provide a window of opportunity for prenatal care and early life interventions to improve child growth 42,43 . Breastfeeding up to two years of age or beyond is a potential strategy to extend the window of opportunity for child protection beyond the second year of life, based on the fact that breast milk remains a source of immune factors, nutrients and micronutrients that are unavailable in usual diets throughout the second year of life, especially in low-income countries $44,45,46,47,48$. This is reflected in the WHO recommendation to continue breastfeeding throughout the second year of life based on the fact that breast milk continues to be a source of key nutrients and immune components that protect against infectious diseases 2,49. During the second year of life, breast milk still remains a source of vitamin A, proteins and other micronutrients that are unavailable in the usual supplementary diet, especially in low-income countries, in which breast milk can provide an average of 35 to $40 \%$ of the total energy requirements 44,48 . Although the quantity of breast milk decreases from $300-900 \mathrm{~mL} / \mathrm{d}$ at the end of the first year to $200-600 \mathrm{~mL} / \mathrm{d}$ in the second year 45,46 , the fat concentration increases, thus increasing the milk's caloric value 47 . In addition, during the second year of breastfeeding, breast milk still conserves its immunological protection properties that may contribute to a decrease in the number of diseases in toddlers 45,46,50. Consequently, breastfeeding up to two years of age or beyond is a possible source of immunological factors, nutrients and micronutrients. Thus, al- 
though the degree of influence of breastfeeding up to two years of age or beyond on child growth or development is still unknown, this fact could potentially extend the window of opportunity beyond the second year of life.

\section{Advantages and disadvantages of the present review}

The main advantage of this review is that it was systematic and did not impose any language restrictions. A drawback of this study is that calculated combined prevalence gathers heterogeneous prevalence data from regions of high prevalence, such as rural areas of Bangladesh (98\%) 13 , and countries of low prevalence such as Iran (1\%) 15 without taking into account population diversity and differences over time, thus hindering the interpretation of the results of these studies. The lack of studies evaluating the effects of breastfeeding up to two years of age or beyond on child growth and development limits any firm conclusions regarding these effects.

\section{Resumo}

Foi realizada uma revisão sistemática para estudar a prevalência mundial de lactância materna por dois anos ou mais, e seus efeitos sobre o crescimento e desenvolvimento infantil. Foram consultadas as bases MEDLINE e LILACS sem restrições de idioma ou tempo, obtendo-se 3.561 títulos. Foram lidos todos os títulos, 453 resumos e 49 artigos. Os artigos com lactância materna $\geq 2$ anos foram incluídos. A análise foi realizada com 19 artigos que cumpriram os critérios de inclusão. Calculou-se uma prevalência combinada de lactância materna aos dois anos de idade de 33\% (IC95\%: 0,23-0,42). Observou-se uma tendência crescente de lactância materna por dois anos ou mais nas últimas décadas no sul da Ásia. Os seis estudos que analisaram os efeitos da lactância materna por dois anos ou mais sobre o crescimento apresentaram resultados contraditórios. Não encontramos associação com o desenvolvimento infantil. Conclui-se que as evidências de efeitos a médio prazo da lactância materna por dois anos ou mais são escassas e contraditórias. Requerem-se estudos adicionais sobre essa prática.

Aleitamento Materno; Desenvolvimento Infantil;

Criança; Crescimento

\section{Conclusion}

The present review provides evidence regarding the lack of publications on the medium-term effects of breastfeeding up to two years of age or beyond on child growth and development. Hence, future research is needed regarding this practice.

\section{Contributors}

C. Delgado contributed to the conception, design, analysis, interpretation, drafting, reviewing and final approval of the manuscript. A. Matijasevich contributed to the conception, design, analysis, interpretation, drafting, reviewing and final approval of the manuscript.

\section{Acknowledgment}

Thanks to César Victora (Universidade Federal de Pelotas, Rio Grande do Sul, Brazil), who provided important suggestions for the final version of this article. 


\section{References}

1. Innocenti Research Centre, United Nations Children's Fund. 1990-2005 Celebrating the Innocenti Declaration on the Protection, Promotion and Support of Breastfeeding: past achievements, present challenges and the way forward for infant and young child feeding. Florence: United Nations Children's Fund; 2005.

2. Hill Z, Edmond K, Kirkwood B. Family and community practices that promote child survival, growth and development: a review of the evidence. Geneva: World Health Organization; 2004.

3. Haggerty PA, Rutstein SO. Breastfeeding and complementary infant feeding, and the postpartum effects. Calverton: Macro International Inc.; 1999. (DHS Comparative Studies, 30).

4. Singh NS, Singh NS. Determinants of duration of breastfeeding amongst women in Manipur. Bangladesh Journal of Medical Science 2012; 10:235-9.

5. Martins E, Giugliani E. Which women breastfeed for 2 years or more? J Pediatr (Rio J.) 2012; 88: 67-73.

6. Horta BL, Bahl R, Martines JC, Victora CG. Evidence on the long-term effects of breastfeeding. Geneva: World Health Organization; 2007.

7. Labayen I, Ruiz JR, Ortega FB, Loit HM, Harro J, Villa I, et al. Exclusive breastfeeding duration and cardiorespiratory fitness in children and adolescents. Am J Clin Nutr 2012; 95:498-505.

8. Oddy WH, Kendall GE, Li J, Jacoby P, Robinson M, de Klerk NH, et al. The long-term effects of breastfeeding on child and adolescent mental health: a pregnancy cohort study followed for 14 years. J Pediatr 2010; 156:568-74.

9. Victora CG, Barros FC, Horta BL, Lima RC. Breastfeeding and school achievement in Brazilian adolescents. Acta Paediatr 2005; 94:1656-60.

10. Kramer MS, Fombonne E, Igumnov S, Vanilovich I, Matush L, Mironova E, et al. Effects of prolonged and exclusive breastfeeding on child behavior and maternal adjustment: evidence from a large, randomized trial. Pediatrics 2008; 121:e435-40.

11. World Health Organization. The optimal duration of exclusive breastfeeding. Report of an expert consultation. Geneva: World Health Organization; 2001.

12. Loney PL, Chambers LW, Bennett KJ, Roberts JG, Stratford PW. Critical appraisal of the health research literature: prevalence or incidence of a health problem. Chronic Dis Can 1998; 19:170-6.

13. Huffman SL, Chowdhury A, Chakraborty J, Simpson NK. Breast-feeding patterns in rural Bangladesh. Am J Clin Nutr 1980; 33:144-54.

14. Simon VGN, Souza JMP, Souza SB. Aleitamento materno, alimentação complementar, sobrepeso e obesidade em pré-escolares. Rev Saúde Pública 2009; 43:60-9.

15. Rakhshani F, Mohammadi M. Continuation of breastfeeding: is this a problem in Southeast Iran? Breastfeed Med 2009; 4:97-100.

16. Briend A, Wojtyniak B, Rowland MGM. Breast feeding, nutritional state, and child survival in rural Bangladesh. Br Med J (Clin Res Ed) 1988; 296: 879-82.
17. Bautista LE. Duration of breast-feeding in the Dominican Republic. Bull Pan Am Health Organ 1996; 120:414-24.

18. Fawzi WW, Herrera MG, Nestel P, Amin AE, Mohamed KA. A longitudinal study of prolonged breastfeeding in relation to child undernutrition. Int J Epidemiol 1998; 27:255-60.

19. Mulder-Sibanda M. Prolonged breastfeeding in Bangladesh: indicators of inadequate feeding practices or mothers' response to children's poor health? Public Health 1999; 113:65-8.

20. Taren D, Chen J. A positive association between extended breast-feeding and nutritional status in rural Hubei Province, People's Republic of China. Am J Clin Nutr 1993; 58:862-7.

21. Joesoef MR, Annest JL, Utomo B. A recent increase of breastfeeding duration in Jakarta, Indonesia. Am J Public Health 1989; 79:36-8.

22. Dang S, Yan H, Yamamoto S, Wang X, Zeng L. Feeding practice among younger Tibetan children living at high altitudes. Eur J Clin Nutr 2005; 59:1022-9.

23. Downs S, Black N. The feasibility of creating a checklist for the assessment of the methodological quality both of randomised and non-randomised studies of health care interventions. J Epidemiol Community Health 1998; 52:377-84.

24. Simondon KB, Simondon F. Mothers prolong breastfeeding of undernourished children in rural Senegal. Int J Epidemiol 1998; 27:490-4.

25. Simondon KB, Simondon F, Costes R, Delaunay V, Diallo A. Breast-feeding is associated with improved growth in length, but not weight, in rural Senegalese toddlers. Am J Clin Nutr 2001; 73: 959-67.

26. Ng'andu NH, Watts TE. Child growth and duration of breast feeding in urban Zambia. J Epidemiol Community Health 1990; 44:281-5.

27. Daniels MC, Adair LS. Breast-feeding influences cognitive development in Filipino children. J Nutr 2005; 135:2589-95.

28. Duazo P, Avila J, Kuzawa CW. Breastfeeding and later psychosocial development in the Philippines. Am J Hum Biol 2010; 22:725-30.

29. Brady JP. Marketing breast milk substitutes: problems and perils throughout the world. Arch Dis Child 2012; 97:529-32.

30. Venancio S, Saldiva S, Escuder M, Giugliani E. The Baby-Friendly Hospital Initiative shows positive effects on breastfeeding indicators in Brazil. J Epidemiol Community Health 2012; 66:914-8.

31. Pérez-Escamilla R. Evidence based breast-feeding promotion: the Baby-Friendly Hospital Initiative. J Nutr 2007; 137:484-7.

32. Cattaneo A. Academy of breastfeeding medicine founder's lecture 2011: inequalities and inequities in breastfeeding: an international perspective. Breastfeed Med 2012; 7:3-9.

33. Santos IS, Mota DM, Matijasevich A, Barros AJD, Barros FCF. Bed-sharing at 3 months and breastfeeding at 1 year in Southern Brazil. J Pediatr 2009; 155:505-9.

34. Dennis CL. Breastfeeding initiation and duration: a 1990-2000 literature review. J Obstet Gynecol Neonatal Nurs 2002; 31:12-32. 
35. Albernaz E, Victora CG, Haisma H, Wright A, Coward WA. Lactation counseling increases breastfeeding duration but not breast milk intake as measured by isotopic methods. J Nutr 2003; 133:205-10.

36. Britton C, McCormick F, Renfrew M, Wade A, King S. Support for breastfeeding mothers. Cochrane Database Syst Rev 2007; 1:CD001141.

37. Kogan MD, Singh GK, Dee DL, Belanoff C, Grummer-Strawn LM. Multivariate analysis of state variation in breastfeeding rates in the United States. Am J Public Health 2008; 98:1872-80.

38. Rea MF. Reflexões sobre a amamentação no Brasil: de como passamos a 10 meses de duração. Cad Saúde Pública 2003; 19 Suppl 1:S37-45.

39. Victora C, Aquino E, Carmo LM, Monteiro C, Barros F, Szwarcwald C. Maternal and child health in Brazil: progress and challenges. Lancet 2011; 377:1863-76.

40. Elsom R, Weaver L. Does breastfeeding beyond one year benefit children? Fetal Matern Med Rev 1999; 11:163-74.

41. Slykerman R, Thompson J, Becroft D, Robinson E, Pryor JE, Clark PM, et al. Breastfeeding and intelligence of preschool children. Acta Paediatr 2005; 94:832-7.

42. Shrimpton R, Victora C, de Onis M, Lima R, Blössner M, Clugston G. Worldwide timing of growth faltering: implications for nutritional interventions. Pediatrics 2001; 107:e75.

43. Victora CG, de Onis M, Hallal PC, Blössner M, Shrimpton R. Worldwide timing of growth faltering: revisiting implications for interventions. Pediatrics 2010; 125:e473-80.
44. Pan American Health Organization. Guiding principles for complementary feeding of the breastfed child. Geneva: World Health Organization; 2003.

45. Jelliffe DB, Jelliffe EF. The volume and composition of human milk in poorly nourished communities. A review. Am J Clin Nutr 1978; 31:492-515.

46. Dewey KG, Finley DA, Lönnerdal B. Breast milk volume and composition during late lactation (7-20 months). J Pediatr Gastroenterol Nutr 1984; 3:713-20.

47. Mandel D, Lubetzky R, Dollberg S, Barak S, Mimouni FB. Fat and energy contents of expressed human breast milk in prolonged lactation. Pediatrics 2005; 116:e432-5.

48. Dewey KG, Brown KH. Update on technical issues concerning complementary feeding of young children in developing countries and implications for intervention programs. Food Nutr Bull 2003; 24:5-28.

49. Saadeh RJ, Labbok MH, Cooney KA, Koniz-Booher P. Breast-feeding: the technical basis and recommendations for action. Geneva: World Health Organization; 1993.

50. Dewey KG, Heinig MJ, Nommsen-Rivers LA. Differences in morbidity between breast-fed and formula-fed infants. J Pediatr 1995; 126(5 Pt 1):696702.

Submitted on 02/May/2012

Final version resubmitted on 24/Sep/2012

Approved on 17/Oct/2012 